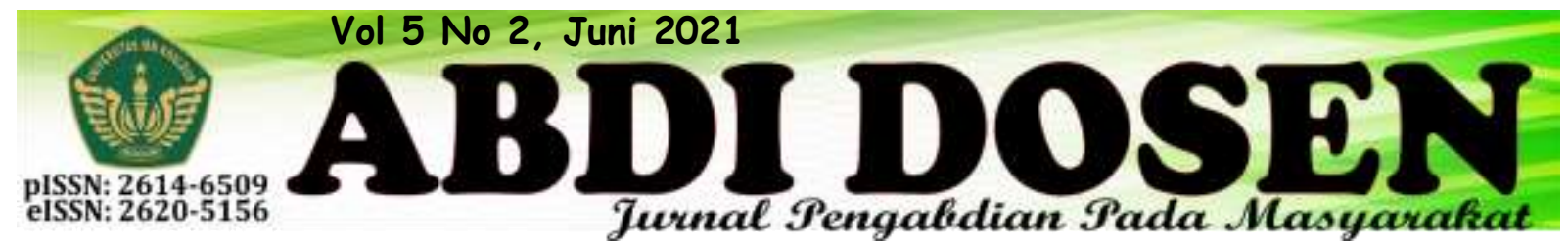

\title{
IMPROVING BASIC LEVEL MANDARIN CONVERSATION SKILLS THROUGH THE PICTURE AND PICTURE METHOD FOR STUDENTS - PRIVATE HIGH SCHOOL STUDENTS DHARMA PANCASILA MEDAN
}

\section{(Peningkatan Keterampilan Percakapan Bahasa Mandarin Tingkat Dasar Melalui Metode Picture and Picture Bagi Siswa SMA Swasta Dharma Pancasila Medan)}

\author{
T. Kasa Rullah Adha ${ }^{1}$, Mhd. Pujiono ${ }^{2}$, dan Intan Erwani ${ }^{3}$ \\ kasa@usu.ac.id ${ }^{1 *}$ \\ mhd.pujiono@usu.ac.id ${ }^{2}$ \\ intanerwani@usu.ac.id ${ }^{3}$ \\ Faculty of Cultural Sciences, University of Sumatera Utara, Medan. ${ }^{1,2,3}$
}

\begin{abstract}
ABSTRAK
Seiring dengan perkembangan zaman dan tuntutan industri 4.0, perkembangan teknologi, ekonomi, sosial, dan budaya yang ketat membuat setiap negara bersaing dan semuanya menjadi sangat mudah untuk diakses. Untuk itu, membangun sumber daya manusia yang pekerja keras, dinamis, terampil, dan menguasai iptek diperlukan untuk mengundang talenta dari negara lain untuk bekerja sama dengan Indonesia. Saat ini Indonesia telah bekerjasama dengan negara lain, salah satunya Tiongkok. Dalam kegiatan pengabdian masyarakat ini akan dilakukan upaya untuk meningkatkan kemampuan berbicara bahasa Mandarin melalui metode picture and picture aktivitas dilakukan secara online melalui aplikasi zoom. Jumlah siswa yang mengikuti kegiatan ini sebanyak 20 siswa SMA Dharma Pancasila. Dalam implementasinya digunakan pendekatan metode picture and picture dengan materi dari power point yang telah dioptimalkan oleh tim service dan khusus untuk siswa SMA. Pengabdian masyarakat ini telah membuahkan hasil yaitu pendampingan dalam meningkatkan percakapan bahasa Mandarin yang berdampak pada peningkatan kemampuan bahasa Mandarin siswa.
\end{abstract}

Kata kunci: keterampilan bahasa Mandarin, sekolah Dharma Pancasila, picture and picture method

\section{ABSTRACT}

Along with the times and the demands of industry 4.0, strict technological, economic, social, and cultural developments make every country compete, and everything becomes very easy to access. For this reason, building human resources that are hard-working, dynamic, skilled, and mastering science and technology is necessary to invite talents from other countries to cooperate with Indonesia. Currently, Indonesia has collaborated with other countries, one of which is China. Therefore, in this community service activity, efforts will be made to improve Mandarin's conversational skills through the picture to picture method. This activity has been carried out online through zoom meetings. The number of students who took part in this activity 
was 20 students of SMA Dharma Pancasila. In its implementation, the picture and picture method approach is used with materials from power points that have been optimized by the service team and specifically for high school students. This community service has resulted in the outcome, namely assistance in improving Chinese conversations, which impacts improving students' Mandarin language skills.

\section{Keywords: Mandarin language skills, Dharma Pancasila High School, picture and picture method}

\section{INTRODUCTION}

In human life, language is fundamental-likewise, social life requires means or tools to relate to one another. The means required is language. Language is also something that can never be separated from humans because language is a tool or means by which we form thoughts and feelings. Also, without language, we will not know how the cultures of our ancestors and the development of science. Language has a role, among others, in shaping experiences in connection with the symbolic response to the world, being a tool that accompanies and shapes the thinking process, processes ideas, and becomes a means of conveying ideas through communication activities.(Kridalaksana, 2009, p. 24; Keraf, 2010, p. 53)

Along with the times and the guidance of industry 4.0, strict technological, economic, social, and cultural developments make every country compete, and everything becomes very easy to access. Information that occurs in a region or country can be found quickly and updated. Open access to view this information, establish communication, and exchange language and culture between countries. President Joko Widodo's speech on October 20, 2019, explained that there are five main priorities to compete with other countries: improving human resources. To develop human resources who are hard-working, dynamic, skilled, and master science and technology. It can invite talents from other countries to cooperate with Indonesia; currently, Indonesia has collaborated with other countries, China. On September 21, 2019, President Joko Widodo met with Chinese President Xi Jinping to discuss increasing cooperation between countries in various sectors such as exchanges and cooperation in tourism, education, students, media, and other trade investment. Therefore, learning foreign languages as provisions in the era of the industrial revolution 4.0 must be prepared in the community.

Dharma Pancasila private high school is a Dharma Pancasila Foundation which is fostered by women who are experienced in the field of education and as the general chairman directly led by Mrs. T. Rizal Nurdin with the mission "To participate in helping the government in the field of education to educate the nation's life." To realize the above mission, this foundation was formed and founded in 1987 by managing schools such as TK (Kindergarten), SMP (Junior High), and SMA (High School) Dharma Pancasila Medan, Accreditation Level A (very good). Currently, Dharma Pancasila Private High School has many students taking various subjects. Each of these subjects has an ultimate goal that students must master, one of which is the Foreign language subject, namely Mandarin. It is hoped that Mandarin language skills can be used not 
only in establishing communication but also as skills that can be taught to the public.

Mandarin is the national language used by people in the People's Republic of China (PRC). Along with the country's increasing economic and technological development, now it has become an international language that the United Nations have recognized, and many countries in the world are starting to learn the language, including Indonesia. The learning methods used in teaching also vary, one of which is picture and picture.

The use of pictures and pictures proves that it can facilitate the emergence of life skills in the language. Unfortunately, this study has not been implemented in the world of education. The ability of life skills

\section{IMPLEMENTATION METHODS}

The community service team will carry out Mandarin conversation training activities to improve Mandarin conversation for Dharma Pancasila Private High School students. The training was carried out for 2 months involving 35 students of Dharma Pancasila Private High School. Determination of participants using interviews conducted in collaboration with the Principal of the Dharma Pancasila Private High School. The method used in this training activity is the lecture method, the question and answer (Q\&A) method (Pujiono, Agustono and Br. Barus, 2020), and the picture and picture.

The lecture method is used to explain the basic knowledge of daily conversations in Mandarin. This method also emphasizes efforts to motivate the participants to have the will and improve their understanding of Mandarin's basics as the primary teaching guide (Agustono, Pujiono and Ayuningtias, 2018; Pujiono, is not trained to students. As a result, many students are only good at memorizing, clever in cognitive knowledge but do not have life skills such as independence, selfconfidence, courage, responsibility, and leadership, and the ability to observe the surrounding environment both physically and events that occur-happening in the neighborhood. Therefore, active learning will effectively learn foreign languages, especially Mandarin, for students of Dharma Pancasila Private High School.

Based on the explanation above, this community service tries to improve conversational skills at the basic level of Mandarin through the picture and picture method for Dharma Pancasila Private High School students in Medan.

Agustono and Adha, 2018).

The discussion and question and answer (Q\&A) method was carried out because the participants needed to know their ability to receive explanations about basic Chinese knowledge. This method allows participants to gain as much knowledge as possible about conversational Chinese.

The picture and picture is a form of active learning that uses images by sorting them into a logical and systematic sequence, such as arranging pictures in a row, showing several pictures, providing an explanation of the information from the pictures (Istarani, 2011; Pujiono and Gapur, 2020). Picture and picture have a difference with the picture media, it is based on the picture and picture arranged sequentially, and the participants who do it are students, while the picture media is a complete picture for the teachers to use in the learning process. With these images' arrangement, the teachers can know and 
understand the students' abilities in arranging pictures sequentially, showing pictures, giving information, and explaining pictures so that students can find their concepts of material by reading

\section{RESULTS AND DISCUSSION}

The community service team to improve Mandarin speech's ability through the picture to picture method for students of SMA Dharma Pancasila, Medan Sunggal sub-district, has conducted socialization and discussions with community service partners, namely the principle of SMA Dharma Pancasila. The socialization was held on September 2, 2020. Through the results of the FGD (Focus Group Discussion) socialization carried out by the team, it provided knowledge about the importance of Mandarin at this time, especially the improvement of conversational skills through the picture to picture method. It can be an input for partners so that the teaching system can be applied, the picture to picture method can be applied, especially in improving the ability to speak Chinese.

\section{Team Socialization}

Following the schedule and place agreed with the community service partner, the community service team came with several students and was welcomed by the partners. The community service team met directly with the Principal, viceprincipal, and Dharma Pancasila students. Even though the activities were carried out during a pandemic and implemented health protocols according to government recommendations, the enthusiasm of students who took part in the service team's socialization had a positive value. The activity began formally, namely with pictures. The existence of pictures provided by the teachers relating to the learning material can make students more active and achieve the learning process's goal, namely increased ability.

a speech by the Principal of SMA DHARMA PANCASILA, namely Drs. H. Ibrahim Daulay, M.Pd., After that, it was followed by remarks by the head of the service team T. Kasa Rullah Adha S.S MTCSOL, and carrying out socialization activities to explain the aims and objectives of the community service program being carried out. After conducting socialization activities.

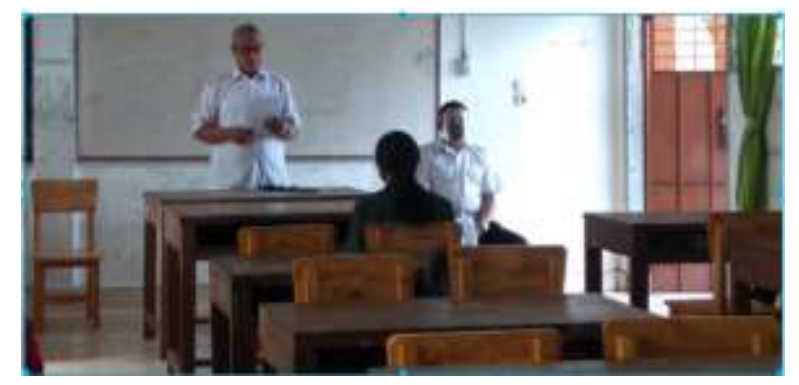

Picture 1. Welcome speech by the Principal of Dharma Pancasila High School Resource: personal documentation

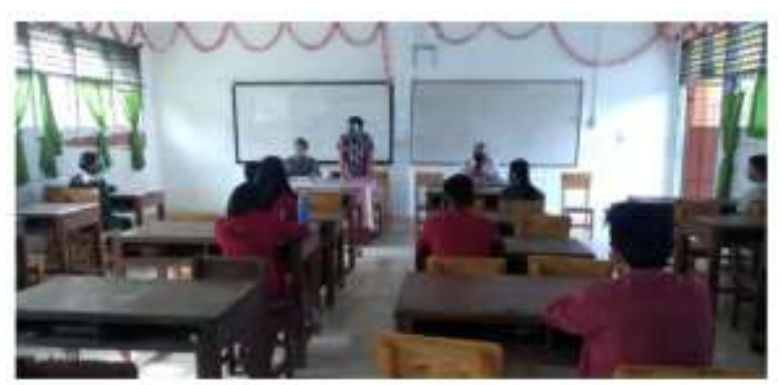

Picture 2. Welcome speech by the head of the Community Service Team

Resource: personal documentation

\section{Lectures and Discussions}

The lecture and discussion methods were facilitated by members of the community service team, namely Mhd. Pujiono., M.Hum., Ph.D, who is the head of the Chinese Language Study Program at 
the USU Faculty of Humanities and is an expert in developing the picture to picture teaching method. The lecture and discussion related to improving foreign language skills with methods to be applied in these service activities, such as vocabulary recognition and vocabulary development through an image that would be used as a conversation.

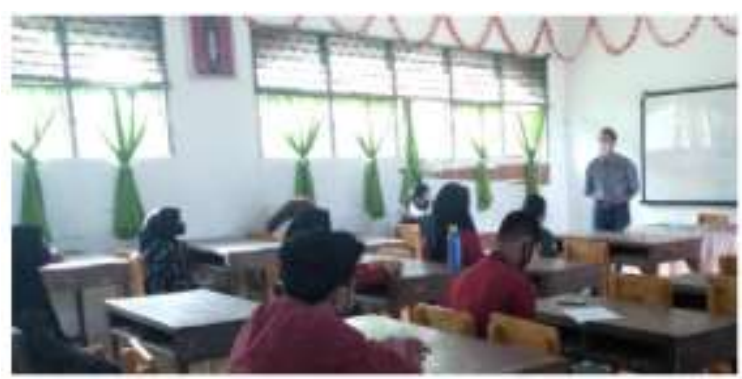

Picture 3. Implementation of socialization activities

Resource: personal documentation

In this activity, students of SMA Dharma Pancasila asked and discussed the problems faced in learning Mandarin. There are three points discussed in this activity; the first is the implementation of a pandemic. At this time, the pandemic has become an obstacle in community service activities carried out in the field. However, these activities were original to be made directly into activities carried out online. Online activities are carried out by using the zoom application. Also, there were questions from students about quotas by using a large enough zoom. So, the community service team provides an internet quota that is used specifically for community service activities.

On the second point, students also complained about the difficulty in pronouncing Mandarin starting from a consonant which is very different from Indonesian. In the application of the picture to picture method, some vocabulary is used related to the images presented, along with the pronunciation and meaning.

Another discussion was about a student who had learned Mandarin at school but still did not understand how much influence the Chinese language currently has. On this question, the service team replied that currently Mandarin had become the Nations' official language, and the important role of Mandarin is currently quite significant, especially in the economic field. Also, the largest population today is the People's Republic of China. If someone wants to master Mandarin well, it is an excellent opportunity to speak to almost the entire population of the world, especially the Republic of China.

The discussion that was carried out has opened knowledge and insight to the participants regarding Mandarin's importance and an increase in Mandarin conversations through the picture and picture method. Students who take part in these activities.

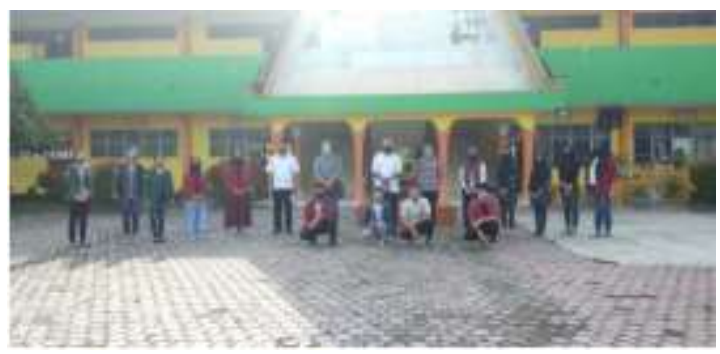

Picture 4. Photo with the Principal and teacher

Resource: personal documentation

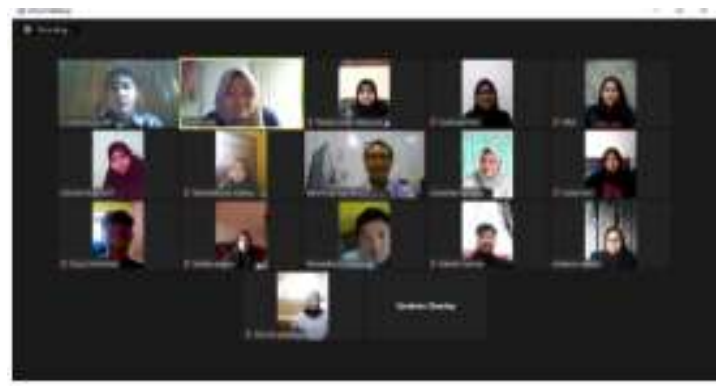

Picture 5. The Mandarin language trainees Resource: personal documentation 

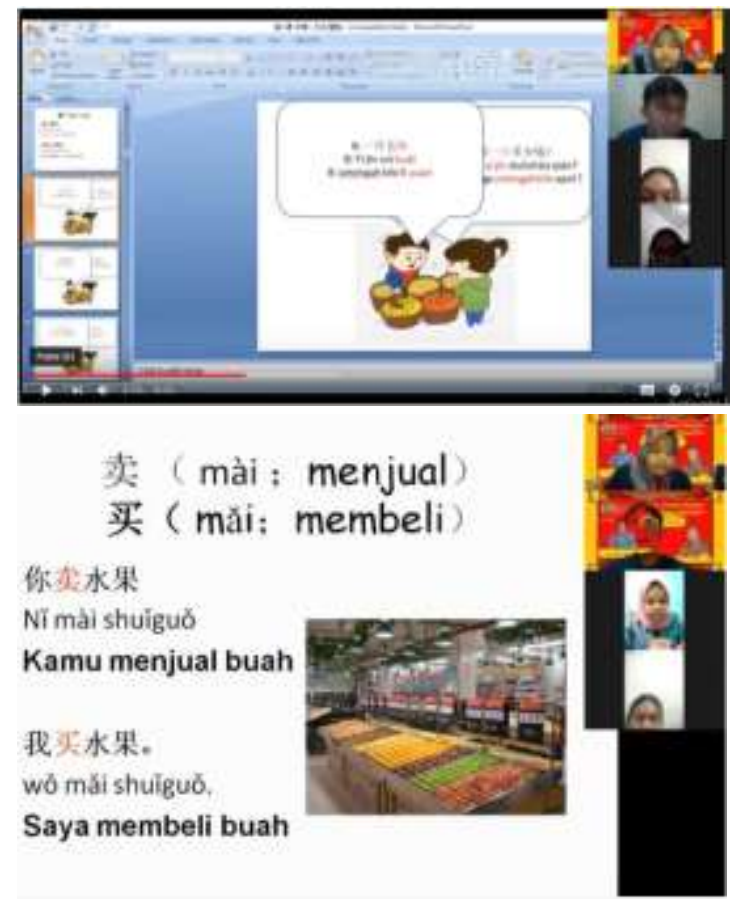

Picture 6. Implementation of online training Resource: personal documentation

The service of implementing picture

\section{CONCLUSIONS}

Community Service Activities The Picture and Picture Method in enhancing Mandarin conversation skills carried out by the team has had a positive impact on increasing the Manadarin language's creativity. In its development, the application of this method aims to make the method applicable in schools. Also, teaching materials are essential in applying these methods. With the addition of

\section{SUGGESTION}

The presence of Mandarin in every school, especially in the city of Medan, makes Mandarin a foreign language that is developing at this time. More people are interested in Mandarin, impacting a person's ability to face the 4.0 era. and picture in improving Mandarin conversation among students of Dharma Pancasila High School has been carried out in the socialization stage with service and training partners. The result is that the team further understands the problems and solutions that the team can contribute to further problems faced by partners, one of which is problems related to online reference materials. The community service team references online reading materials and makes videos about Chinese conversations by Dharma Pancasila High School students.

Subsequently, there was assistance in increasing conversation. As a follow-up to the training results, the service team assists in increasing conversation, such as opening online discussion media for conversations in Mandarin.

references to teaching materials, it can also add insight into students' knowledge in learning foreign languages, especially learning Mandarin.

Furthermore, the team's mentoring is also carried out, aiming to improve student abilities so that students are more enthusiastic and active in using Mandarin in the school environment and community environment.

Therefore there needs to be cooperation from other parties, including the government, business people, and other institutional institutions, to provide financial assistance and guidance on improving Mandarin. 


\section{REFERENCES}

Agustono, B., Pujiono, M. and Ayuningtias, N. (2018) 'IbM Pengembangan Rajutan di Kampung Aur Medan', LOGISTA - Jurnal Ilmiah Pengabdian kepada Masyarakat, 2(1), p. 21. doi: 10.25077/logista.2.1.2130.2018 .

Istarani (2011) 58 Model Pelajaran Inovatif Referensi Guru dalam. Medan: CV. ISCOM.

Keraf, G. (2010) Diksi dan Gaya Bahasa. Jakarta: PT Gramedia Pustaka Utama.

Kridalaksana, H. (2009) Kamus Linguistik. 4th edn. Jakarta: PT. Gramedia.

Pujiono, M., Agustono, B. and Adha, T. K. R. (2018) 'Community Service on the Improvement of Clean Environement Based on Waste Bank in the SubDistrict of Bahari Belawan (PKM
Peningkatan Kebersihan Lingkungan Berbasis Bank Sampah di Kelurahan Bahari Belawan)', LOGIST A - Jurnal Ilmiah Pengabdian kepada Masyarakat, 2(2), p. 9. doi: 10.25077/logista.2.2.9-16.2018.

Pujiono, M., Agustono, B. and Br. Barus, M. (2020) 'Japanese Conversation Learning through "Active Learning" for Yafsi Volunteers in Medan', Dinamisia: Jurnal Pengabdian Kepada Masyarakat, 4(2), pp. 222230. doi: 10.31849/dinamisia.v4i2.3 629.

Pujiono, M. and Gapur, A. (2020) 'KEMAMPUAN MENULIS MAHASISWA DEPARTEMEN SASTRA JEPANG SEMESTER II MELALUI MODEL PEMBELAJA RAN PICTURE AND PICTURE'. doi: $10.5281 /$ zenodo.4271146. 